\section{THE SCIENCE FACULTY OF THE UNIVERSITY OF LONDON.}

$A \mathrm{~T}$ the meeting of the faculty of science on October 30 which was held in the lecture-room of the physiological laboratory of the London University, Prof. J. Millar Thomson, F.R.S., was unanimously elected dean of the faculty in succession to Dr. Augustus D. Waller, F.R.S., who gave the following address in vacating this office. Dr. Waller said :-

"In vacating the chair that I have had the honour to hold during the last four years as dean of the faculty of science, it may be expected of me that I should review the work of the faculty during that period.

"I shall not, however, attempt to draw up any elaborate digest of the proceedings recorded in our minutes. I shall limit myself to directing your particular attention to two subjects that in my opinion are calculated to be of cardinal importance in the future development of the faculty, and that have been prominent before my mind during my term of office.

"The first of these two subjects relates to the faculty board, composed of the representatives of its several boards of studies. In the constitution of the University, as reformed ten years ago, the official organs of intermediation between the teachers and the Senate are the boards of studies, and the several faculties in relation to those boards on the one hand, and to the Senate and academic council on the other, have been purely consultative, occasional, and of little significance. The official and regular function of the faculties is little more than electoral; every four years it elects two representatives on the Senate.

"It is recognised by those responsible for the development of the University that each faculty is properly the place of convergence at which the particular interests and requirements of its boards of studies should be united, coordinated, and promoted. Under the present constitution the official utterances of individual boards are liable not to produce their due effect in the councils of the University. The faculty itself is too large and in other ways unsuitable for the adequate discussion of practical details. Yet if the influence of its boards of studies is not to be frittered away piecemeal, it must be united and unified by means of the faculty. It is this unification of educational interests that will be the principal function of the faculty board, composed as it is of representatives of all the boards of studies concerned.

"The full remedy of subdivision of influence is not possible under the present statutes of the University, but a very considerable step in the right direction cain be taken if full use is made of the faculty board, at which the opinion of each particular board of studies can be considered and modified if need be, and reinforced by the opinion of related boards. Full expert discussion of educational requirements at the faculty board, and, if need be, at the faculty itself, would promote the interests common to all studies far more effectually than is the case at present.

"The second subject to which I wish to invite the attention of the faculty relates to the organisation of means for the advancement of science and learning. We know this University as an organ of examination. We are assisting at the consolidation and development of its teaching side at its colleges and schools and at the University itself.

"The highest function of education is the fostering of initiative, in which the acquisition of further knowledge by the teachers of already acquired knowledge is the principal factor.

"The University can fulfil its satutory duty to "promote research and the advancement of science and learning,' not only by its fostering care of its colleges and schools, but by itself acting as a focus of light and leading, served by the collective efforts of all its college teachers, serving thereby the collective interests of all its colleges.

"The room in which we are now met represents an outcome of that tendency. We are attempting to accomplish in physiology a typical concentration of its best elements such as we believe to be desirable in the case of all the principal subjects, belonging to letters as well as to science.
"During the past six years all the teachers of physiology in London, as well as several teacliers of physiology belonging to the great provincial and colonial schools, have contributed of their best knowledge in this lecture-room. I do not propose to weary you by proclaiming to the faculty the special requirements or the special merits of any one branch of science. All that I feel justified in doing is to indicate to the faculty of science a concerted effort within the domain of that subject that I believe to be worthy of consideration in other provinces of science and learning.

"I shall, however, lay stress in conclusion upon what I conceive to be the most special and most hopeful sign of merit in this six-year-old object-lesson in the organisation of learning. The principal concern of this lectureroom consists in knowledge at first-hand, knowledge in the nascent state and in the making. The best teachers and many of the best students of practically all the colleges and schools of the University have assisted in its work. The colleges have given of their best, knowledge at firsthand communicated by the men who have gathered it. And the gift has augmented the wealth of the givers.

"I shall be confirmed by every physiologist when I state that during the last few years physiological education has been promoted by the special courses of advanced lectures in physiology, that have become established in the colleges as well as at the University itself.

"The gift of the colleges to the University has been to the gain of the University and to the gain of the colleges.

"Shall I be held as too sanguine if, in conclusion, I venture to hope that in the great efforts required of the University to fulfil its function as a seat of learning the feeble effort made during the last six years in a limited province within the faculty of science may not prove to have been quite fruitless?"

\section{ENTERIC FEVER IN INDIA.}

THE subject of enteric or typhoid fever is of considerable importance in India, particularly to the British troops stationed there, and the Indian Government has therefore been well advised to institute an inquiry into the factors influencing the occurrence of the disease. ${ }^{2}$ The work has been carried out under the direction of Lieut.Colonel Semple, I.M.S., and Captain Grieg, I.M.S., at the Central Research Institute, Kasauli. The problems to be solved were:-(I) What is the nature and duration of the saprophytic life of the Bacillus typhosus? (2) What is the duration of the life of the Bacillus typhosus within the human host? (3) How are epidemics produced? As a result of a large series of experiments and observations, evidence is brought forward to show that ( $\mathrm{r}$ ) the Bacillu's typhosus continues to be excreted for long periods in the urine and fæces of a certain percentage of patients convalescent from enteric fever, the number in the urine being very large, and the excretion being markedly intermittent; (2) the "chronic bacilli carrier" exists in different units in India, and can cause epidemics and cases of enteric fever; (3) enteric fever orderlies may become " chronic bacilli carriers"; (4) in India the saprophytic existence of the Bacillus typhosus outside the human host is short. Thus in fæces and in urine kept at $80^{\circ} \mathrm{F}$. in the dark, the typhoid bacillus had died out in ninety-six hours and seventy-two hours respectively, and an exposure to the sun of thin cotton and of blanket soaked with urine containing typhoid bacilli for two hours and six hours respectively proved fatal to the organism.

The general conclusion arrived at is that the problem of the prevention of enteric fever among the British troops in India is the detection and isolation of the individual harbouring the Bacillus typhosus. We should have expected, however, some reference to anti-typhoid vaccination in this connection.

The report is a very valuable one, and contains the details of the experiments performed and tabular statements of the cases investigated.

1 Scientific Memoirs bv Officers of the Medical and Sanitary Departments of the Government of India. No. $3^{2}$. (Calcutta, r908.)

No. 2036, 'VOL. 79] 